\title{
First meeting of commission gives Massey a boost in plotting viable future for NSF
}

\begin{abstract}
Washington. In creating the Commission on the Future of the US National Science Foundation (NSF), the foundation's director, Walter Massey, was seeking help in balancing a congressional directive to use science to strengthen the nation's economy against the foundation's traditional role of supporting academic research. Judging by last week's first meeting of the commission, Massey stands a good chance of walking that fine line.
\end{abstract}

The commission faces a tall order: to deliver a report by 20 November to the National Science Board, NSF's governing body, setting out principles for NSF to follow in maintaining its relevance into the twenty-first century. The timetable was determined by the November presidential election, although its observations will be included in a strategic plan that NSF has been working on since January.

Gathered at NSF headquarters barely a week after its 15 members - prominent university administrators, researchers and industrial leaders - were selected, the commission not surprisingly spent the first half of its half-day meeting sorting out its task. Although Massey asked the science board to form the commission less than two weeks after the US Senate passed an appropriations bill calling on NSF "to take a more activist role" in transforming the results of basic research into commercial products, NSF officials insist that the commission is not being asked to respond to current events. What is needed, they say, is a thoughtful look into the future by people familiar with the work of the foundation but not dependent on it.

The stakes are high. Rank-and-file university scientists are concerned that NSF may turn its back on investigator-initiated research in favour of directed programmes catering to industrial needs. The result, they say, could be an irreversible decline in an educational system that is recognized as the best in the world. At the same time, politicians are clamouring for a higher rate of return on federal research dollars and looking for high-technology products that will reduce the country's trade deficit.

The discussion at the meeting reflected that ambivalence. No sooner did one member put forward an expansive view of NSF's role, stressing the need for university and industrial scientists to work closely together, than another member reminded the commission of the foundation's basic mission to support academic research and train the next generation of scientists. Of course, some of the sparring may have been for effect. After an invited speaker, John McTague of Ford Motor Company, described what industry expects from NSF as part of a presentation on the forces shaping industrial research, Marye Anne Foxe, a chemist at the University of Texas at Austin, responded with a quotation from an influential 1945 report by Vannevar Bush entitled Science, The Endless Frontier that led to the creation of NSF.

that they do not expect any recommendations from the commission to influence the proposed 1994 budget to be presented to Congress in January, researchers will naturally be looking out for signs of a shift. Similarly, commission members say that they do not wish to labour in vain.

"I would hope that our impact would appear in the federal programs for the diffusion of technology", says William Danforth, chancellor of Washington University in St Louis, Missouri, and cochair of the commission. "Otherwise, we're wasting our time."

It is not at all clear which federal agency should be given the task of ensuring that research is more efficiently turned into products. Commission member Lewis Branscomb of Harvard University says that existing programmes within the departments of Commerce, Defense and Energy do not seem up to the job and that individual agencies with large research portfolios have missions linked to specific sectors of the economy. Branscomb and others are concerned that the government may turn to NSF as a last resort and give

"The simplest and most effective way in which the government can strengthen industrial research", Bush wrote, "is to support basic research and to develop scientific talent". When Foxe asked if the commission believed that Bush's words must now be altered to fit today's world, McTague went one better by replying, "I' $d$ engrave them in gold on the walls of the foundation".

But words alone are not enough to clarify NSF's mission. Although NSF officials say it an assignment too large to handle.

The key to Massey's tightrope-walking strategy may lie in words from St Augustine as translated by Harold Shapiro, president of Princeton University, who spoke to the commission about changes occurring within US universities. "Not new, but in a new way", St Augustine said about how to teach the Scriptures. Massey may well be looking for the same formula at NSF.

Jeffrey Mervis

\section{User fees advance in Congress}

Washington. User fees paid by drug companies to supplement the budget of the US Food and Drug Administration (FDA) inched closer to becoming a reality last week after winning the approval of an important congressional committee in the House of Representatives. The proposal, the only one of many introduced since the mid1980 s to have won the support of industry, Congress and the president, would allow the cash-starved FDA to recruit 600 more staff to clear the backlog of new drug applications awaiting review by FDA and expedite the drug review and approval process (see Nature 358, 616; 1992).

Co-sponsored by Representatives John Dingell (Democrat, Michigan) and Henry Waxman (Democrat, California), the pro- posal would generate about $\$ 330$ million during the next five years through three types of user fees - a one-time payment for new drug applications and annual fees on all approved prescription drugs on the market and on manufacturing establishments. David Kessler, the FDA commissioner, has said that the fees would enable the agency to eliminate its backlog of new drug applications within two years.

Although the bill cuts in half the fees charged to smaller biotechnology companies (those with fewer than 500 employees and no FDA-approved products), those companies are pushing for an exemption for start-up companies with little or no revenue from sales.

Diane Gershon 